This section presents interviews with evaluators whose work can illustrate, in a specific evaluation study, the application of different models, theories, and principles described in evaluation literature. These interviews should also exemplify the choices that evaluators make in the course of planning and conducting an evaluation. Entries in this section will begin with a brief description of the evaluation to provide a foundation for the interview. The focus will be on the dialogue between the section editor and the evaluator to learn more about the choices made, the models followed, the constraints and opportunities that emerged as the study progressed, and the evaluator's assessment of the study itself. The section editor will provide commentary as needed to point out important attributes of the evaluation itself and to highlight connections between the evaluator's comments and relevant literature or issues in the field of evaluation.

Please send any suggestions about evaluators/evaluations that might be the subject of this column to the section editor, Jody Fitzpatrick, at jfitzpat@carbon. cudenver.edu.

\title{
Summary of the STEP Evaluation
}

\section{DAVID FETTERMAN}

\section{INTRODUCTION}

David Fetterman, the past president of the American Evaluation Association and Director of the MA Policy Analysis and Evaluation Program at Stanford University, is the founder and primary developer of the empowerment approach to evaluation. The American Journal of Evaluation has published several articles by Dr. Fetterman on this approach. In 1997, however, Dr. Fetterman undertook a complex, three-year evaluation of the Stanford Teacher Education Program (STEP), and chose to follow a different model. In an effort to learn more about the practice of major model builders in evaluation, this column will focus on the STEP evaluation and the choices Dr. Fetterman made in conducting that study. This project was selected to illustrate Dr. Fetterman's work because the evaluation continues to receive much attention both at Stanford and nationally in the teacher education arena and because Dr. Fetterman felt that readers would learn, as he did, from the process of this study.

David Fetterman • Stanford University, School of Education, Room 333 Cubberly, 485 Lasuen Hall, Stanford, CA 94305-3096.

American Journal of Evaluation, Vol. 21, No. 2, 2000, pp. 239-241. All rights of reproduction in any form reserved. ISSN: $1098-2140$

Copyright (C) 2000 by American Evaluation Association. 


\section{SUMMARY OF THE STEP EVALUATION}

The president of Stanford University, Gerhard Casper, requested an evaluation of the Stanford Teacher Education Program (STEP). The first phase of the evaluation was formative, designed to provide information that might be used to refine and improve the program. It concluded at the end of the 1997-1998 academic year. Findings and recommendations from this phase of the evaluation were reported in various forms, including a formal summer school evaluation report (Fetterman, Dunlap, Greenfield, \& Yoo 1997), over 30 memoranda, and various informal exchanges and discussions.

The second stage of this evaluation was summative in nature, providing an overall assessment of the program (Fetterman, Connors, Dunlap, Brower, Matos, \& Paik, 1999). The final report highlights program evaluation findings and recommendations, focusing on the following topics and issues: unity of purpose or mission, curriculum, research, alumni contact, professional development schools/university school partnerships, faculty involvement, excellence in teaching, and length of the program. Specific program components also were highlighted in the year-long program evaluation report, including admissions, placement, supervision, and portfolios. (See the STEP web site for copies of all evaluation reports: http://www.stanford.edu/ davidf/step.html.)

\section{THE METHODOLOGY}

The evaluation relied on traditional educational evaluation steps and techniques, including a needs assessment; a plan of action; data collection (interviews, observations, and surveys); data analysis; and reporting findings and recommendations. Data collection involved a review of curricular, accreditation, and financial records, as well as interviews with faculty and students, and observations of classroom activity. Informal interviews were conducted with every student in the program. Focus groups were conducted with students each quarter and with alumni from the classes of '95, '96, and '97. More than 20 faculty interviews were conducted. Survey response rates were typically high (90\% to 100\%) for master teachers, current STEP students, and alumni. Data collection also relied on the use of a variety of technological tools, including digital photography of classroom activity, Web surveys, and evaluation team videoconferencing on the Internet. Data analysis was facilitated by weekly evaluation team meetings and frequent database sorts. Formal and informal reports were provided in the spirit of formative evaluation. Responses to preliminary evaluation findings and recommendations were used as additional data concerning program operations. (A detailed description of the methodology is presented in Fetterman, Connors, Dunlap, Brower, \& Matos, 1998.)

\section{BRIEF DESCRIPTION OF STEP}

STEP is a 12-month teacher education program in the Stanford University School of Education, offering both a master's degree and a secondary school teaching credential. Subject area specializations include English, languages, mathematics, sciences, and social studies. The program also offers a Cross-cultural, Language, and Academic Development 
(CLAD) emphasis for students who plan to teach second language learners. The 1997-98 class enrollment was 58 students. Tuition and board are approximately $\$ 30,000$.

The program introduces students to teaching experiences during the summer quarter through the summer school program under the guidance of a master teacher. Students are also required to take course work during this period. Students enter the academic year with a nine-month teaching placement, which begins in the fall quarter under the supervision of a cooperating teacher and field supervisor. Students also are required to take the School of Education master's degree and state-required course work throughout the year.

The program administration includes a faculty sponsor, director, placement coordinator, student services coordinator, lead supervisor, field supervisors, and a program assistant. In addition, the program has a summer school coordinator/liaison and part-time undergraduate and doctoral students.

\section{REFERENCES}

Fetterman, D. M., Connors, W., Dunlap, K., Brower, G., Matos, T., \& Paik, S. (1999). Stanford Teacher Education Program 1997-98 Evaluation. Stanford, CA: Stanford University.

Fetterman, D. M., Connors, W., Dunlap, K., Brower, G., \& Matos, T. (1998). Stanford Teacher Education Program 1997-98 Evaluation Report. Stanford, CA: School of Education, Stanford University.

Fetterman, D. M., Dunlap, K., Greenfield, A., \& Yoo, J. (1997). Stanford Teacher Education Program 1997 Summer School Evaluation Report. Stanford, CA: Stanford University. 